\title{
11
}

\section{Rethinking Rape Law Reform: Challenges and Possibilities}

\author{
Wendy Larcombe
}

\section{Rape Law Reform}

Having been involved with rape law reform in different roles and capacities over the past 25 years, it is disappointing to be arguing that the main challenge to be addressed in this field of law in the future is the same as it was 25 and more years ago. That challenge is: the legal system, and in particular the criminal justice system, must better support the justice needs of sexual violence survivors.

I want to make this argument with some care because Australian jurisdictions have now experienced more than 40 years of rape law reforms intended to:

- redress gender bias in the criminal law's definition of and response to rape;

- make the law more reflective of the 'reality' of sexual violence - who perpetrates it, against whom, in what circumstances and contexts; and

- improve the experience for complainants participating in criminal prosecutions.

1 Associate Professor, Law School, University of Melbourne. 
Those legislative reforms - to the substantive criminal law, to evidence law and court procedures - have been driven by the immense determination and intelligence of feminist activists and victim/survivor advocates. Every change has been hard-fought and hard-won.

And much has been achieved. As a feminist and queer scholar, I view it as a significant achievement that rape and other forms of sexual offending against male, trans and intersex people are now recognised, while only non-consensual (and not consensual) sexual activity within lesbian, gay, bisexual and queer communities is now prosecuted. Prior to the statutory reforms of recent decades this was not the case.

It is also highly significant that there is no longer legal immunity for husbands who rape their wives. Although the High Court told us in 2012 that there was no such immunity under the common law in Australia during the $20^{\text {th }}$ century, ${ }^{2}$ as no one had known that that was the case, the legislative reforms to criminalise rape in marriage from the mid-1980s onward were critically important.

Other significant advances include:

- that complainants can no longer be routinely cross-examined about their general sexual history;

- that a rape complaint is no longer disqualified if the victim/survivor cannot be sure whether it was a penis or a finger or an object that was inserted into their vagina or anus;

- that judges can no longer give routine warnings about the unreliability of the evidence that women and children provide in sexual matters and, hence, the need for corroboration;

- the development of affirmative, statutory definitions of consent as 'free agreement' and codification of circumstances that preclude consent;

- restrictions on the defence use of a complainant's confidential counselling records;

- provisions for vulnerable witnesses to give evidence remotely and/or have a support person sit with them; and

$2 \quad$ PGA $v$ The Queen [2012] 245 CLR 355. See Wendy Larcombe and Mary Heath, 'Developing the Common Law and Rewriting the History of Rape in Marriage in Australia: PGA v The Queen' (2012) 34 Sydney Law Review 785. 
- specialist police units and specialist court lists for sexual offences in which investigators, judges, prosecutors and court personnel have undertaken training in the needs and experiences of sexual violence victims/survivors.

The list of positive reforms goes on. Much has been achieved. Yet, frustratingly, the primary challenge for law reform remains the same. To better support the justice needs of sexual violence survivors, two core problems must be addressed.

\section{A. Problem 1: The criminal justice system does not provide an accessible, effective resolution to sexual offending for the vast majority of victims/survivors}

The Australian Bureau of Statistics ${ }^{3}$ reports that 17 per cent of women and 4 per cent of men have experienced sexual assault since the age of 15 years. In addition, 12 per cent of women and 4.5 per cent of men experienced sexual assault before the age of 15 years. It is estimated that fewer than one in five sexual assaults is reported to the police and that figure has not increased in response to reforms. ${ }^{4}$ Of those reported assaults, fewer than one in five will be prosecuted and approximately $10-15$ per cent will register a conviction on any charge. This means that the overall conviction rate for sexual assaults in Australia is less than 5 per cent and, in some jurisdictions, less than 1 per cent.

Paradoxically, conviction rates for rape have fallen across the 40 years of feminist-inspired law reform. The (widely known) low conviction rate now contributes to low reporting. It also confirms the public perception that rape survivors are treated poorly and their claims not taken seriously

3 Australian Bureau of Statistics (ABS) (2012). Personal Safety Survey: 4906.0 (Canberra: Australian Bureau of Statistics).

4 Statistics on rape case attrition are reviewed at length in Wendy Larcombe, 'Sex Offender Risk Assessment: The Need to Place Recidivism Research in the Context of Attrition in the Criminal Justice System' (2012) 18(4) Violence Against Women 482; W Larcombe, 'Falling Rape Conviction Rates: (Some) Feminist Aims and Measures for Rape Law' (2011) 19(1) Feminist Legal Studies 27; Kathleen Daly and Brigitte Bouhours, 'Rape and Attrition in the Legal Process: A Comparative Analysis of Five Countries', in M Tonry (ed), Crime and Justice: An Annual Review of Research (University of Chicago Press, 2010) Vol 39, 485-565. 
in the criminal justice process. ${ }^{5}$ As a result, more than 80 per cent of people who experience sexual violence do not engage with the criminal justice system.

\section{B. Problem 2: Those convictions that are secured for sexual assault are unrepresentative of the most common forms of sexual violence experienced by women and children}

Most sexual assaults are committed against women and children by known male family members, friends or acquaintances, in private homes, and in circumstances where force or violence are not necessary to effect the assault. In many instances, women and children are subjected to repeated offences by the same offender. ${ }^{6} \mathrm{ABS}$ and police data show that young women aged 16 to 24, Indigenous and Torres Strait Islander women, and people with cognitive impairments or intellectual disabilities are particularly vulnerable to sexual assault. It is this offending that victim advocates and feminist reformers have wanted recognised and criminalised through legislative amendments. That is why the focus has been on removing requirements for force and resistance, abolishing spousal immunity, and requiring free and voluntary consent (from a person who has the capacity at the time to provide such consent).

However, if we look at the outcomes of criminal prosecutions, rather than the statutory provisions, it is evident that the criminal justice process continues to reproduce what Susan Estrich called the 'real rape' stereotype. ${ }^{7}$ The cases that secure, and those that fail to secure, criminal convictions tell us that it is still very difficult to successfully prosecute rape or sexual assault when:

- the offender is a current or former intimate partner;

- no weapon or threats of physical violence were used;

- the victim did not sustain physical injury;

5 See especially Denise Lievore, Non-reporting and Hidden Recording of Sexual Assault: An International Literature Review (Australian Institute of Criminology for the Commonwealth Office of the Status of Women, 2003); Haley Clark, 'What is the Justice System Willing to Offer?: Understanding Sexual Assault Victim/Survivors' Criminal Justice Needs', Family Matters No 85 (Australian Institute of Family Studies, 2010).

6 ABS, above $\mathrm{n} 3$; Lievore, above $\mathrm{n} 5$.

7 Susan Estrich, Real Rape (Harvard University Press, 1987). 
- the victim did not resist or protest;

- the victim was heavily intoxicated (by drugs or alcohol) but not unconscious;

- the victim has a history of mental health difficulties, has previously experienced or reported sexual assault, or has a criminal conviction.

In short, the stereotype of 'real rape' continues to disqualify the majority of women and many members of highly vulnerable groups who experience sexual assault from securing legal redress. Victims/survivors with particular attributes and capacities are still preferred in the criminal justice process. ${ }^{8}$ Just as problematic, rape case attrition is highly skewed in favour of prosecuting a small class of offenders. As I've argued elsewhere, those convicted of sex offences are not representative of those who commit sex offences, nor are they always representative of those who pose the most 'danger' to women and children.'

A distorted idea of the sex offender who merits criminal punishment has only been exacerbated in recent years by (non-feminist) criminal law reform that has introduced measures such as post-sentence detention, ongoing supervision and registration of 'serious' sex offenders. These provisions perpetuate (false) beliefs that sexual offenders are a small group of deviant psychopaths, with unique characteristics who pose a distinct risk to the community. This 'myth' undermines attempts to criminalise commonplace sexual offending.

In sum, the criminal law, in practice, is not providing an effective, accessible justice option for victims/survivors and, by not being able to prosecute the most common forms of sexual offending practised in the community, it is actively contributing to the minimisation and normalisation of such violence, while reproducing a distorted idea of 'real rape' and deviant 'sexual offenders'.

8 Wendy Larcombe, 'The Ideal Victim v Successful Rape Complainants: Not What You Might Expect' (2002) 10(2) Feminist Legal Studies 131.

9 Larcombe, 'Sex Offender Risk Assessment', above n 4. 


\section{What Should the Legal and Policy Responses Be, and Why?}

The following three proposals are my priorities for further law reform. Note that these are in the 'blue sky' domain of what is needed, not necessarily the domain of 'what is immediately feasible', or 'politically realistic'.

\section{A. Proposal 1: Judge-alone trials}

In line with practice in Canada, and with calls from commentators and service providers in New Zealand and England and Wales, I would advocate that trials for sexual offences should be heard by judge alone. I know this proposal will be contentious, but I believe that removing the jury is the single measure most likely to improve criminal prosecutions and outcomes for sexual offences. More particularly, I believe it is a necessary step for rebuilding victims/survivors' confidence in the criminal justice system, and ensuring convictions in 'ordinary' cases of sexual offending.

The jury is currently perceived by various stakeholders as the 'weakest link' in the criminal prosecution of sexual offences. ${ }^{10}$ Much of the attrition that marks sexual cases in the criminal process is attributable to the fact that decision-makers at each stage anticipate (correctly) that at least some jurors on any panel will endorse so-called 'rape myths' and 'victimblaming attitudes'. Such beliefs and attitudes are known to be widely held and to predetermine interpretations of evidence and fact-finding in rape cases. This is why we have already created specialised courts (or court lists) for sexual offences in which judges, prosecutors and other court personnel have received training in the distinct features and diverse forms of sexual offending. The average person simply does not have a sound understanding of when or how sexual offending occurs, how it is effected by perpetrators, and how survivors may respond. This makes sexual offending ill-suited to jury determination.

A range of measures have been developed or proposed in recent years to try to educate criminal juries about sexual assault and to correct common misconceptions. Why is jury education not preferable to judge-only trials? First, we cannot know whether jury education works to remediate

10 Wendy Larcombe et al, “I Think It's Rape and I Think He Would Be Found Not Guilty”: Focus Group Perceptions of (un)Reasonable Belief in Consent in Rape Law' (2016) 25(5) Social \& Legal Studies 611-629. 
misconceptions and flawed decision-making (decision-making based on false assumptions and stereotypes). We cannot eavesdrop on jury deliberations and the verdict does not reveal the reasoning. In any event, jury education cannot be done efficiently. If an expert has to be sworn in for every sexual offence trial in the county or district courts, experts will be spending most of their time in court speaking to juries about sexual offending. It is simply more efficient to educate the judiciary and allow them to determine the questions of fact as well as those of law.

Other potential benefits of judge-alone trials discussed in the literature include that they:

- ensure decision-making based on legally relevant factors and evidence;

- mean that published reasons are available - everyone can know where or why a prosecution or defence failed (or succeeded);

- solve problems with jury understanding of the proper uses (and limitations) of tendency or context evidence, forensic evidence and expert witness testimony;

- eliminate appeals based on inadequate or inaccurate jury directions;

- may be fairer to defendants who fit negative stereotypes or who are charged with highly stigmatised offences;

- afford the court greater flexibility in management of trials;

- may enable prosecutors and defence to focus more on testing of evidence and less on jury understanding and persuasion;

- may assist to secure community and professional confidence in criminal prosecutions and outcomes - undermined currently by the expectation that criminal prosecutions will be determined by jury members' beliefs and attitudes.

Note that I do not imagine that judge-alone trials will be a silver bullet that solves all the issues that have been identified with rape trials. And I do not for a minute think that all judges, even if they have been selected and trained to sit on sexual offences lists, will have a sensitive understanding of sexual offending and survivor responses. But we would be able to identify ongoing issues and problems through the published reasons. And wrongful acquittals will be potentially correctable by an appeal court. ${ }^{11}$ Jury education does not enable such review.

11 See, for example, the decision of the Court of Appeal of Alberta on an appeal against acquittal in $R v$ Wagar, 2015 ABCA 327 (CanLII). 


\section{B. Proposal 2: Promote alternative justice options utilising civil law and civil society}

While it is essential that the criminal justice response to sexual offending is improved, in order to offer effective forms of redress to all survivors of sexual violence, the criminal law's monopoly on sexual assault must be broken. Rape and sexual assault cannot always, and perhaps should not always, be criminally prosecuted. Depending on the context and the victim/survivor's wishes, it may be more appropriate to respond to sexual assault as a tortious wrong, or through the frameworks providing protection against sexual harassment and discrimination, or through family violence protection orders, or through family conferencing or mediation, or through 'restorative justice' conferencing - via public funded or private services.

Until relatively recently, the criminal law's monopoly on rape and sexual assault has been supported by feminist efforts to ensure that sexual violence is formally treated as criminal conduct, not merely as 'bad' or 'unwanted sex'. However, the rise and rise of 'tough on crime' politics and, with it, the increasing stigma associated with sexual offending have changed the politics of this field. Those changes have not been positive - especially considering that many victims/survivors do not want to bring the shame and stigma of identifying a 'sex offender' in their immediate social or family circle. As a result, 'ordinary' forms of sexual assault may now be more readily acknowledged and redressed if they are not prosecuted as a crime.

And we may do less harm to complainants in the process. Sexual assault is a violation of a person's autonomy and integrity. That injury has been compounded in traditional criminal justice processes by the victim/ survivor being re-placed in a powerless position as a witness for the prosecution, often feeling that they are again being used instrumentally to advance others' interests (society's this time), while their choices and needs are disregarded or belittled. This positioning of the survivor echoes and triggers elements of the original assault, generating distress and often prolonging recovery. ${ }^{12}$

12 Clark, above n 5. 
These shortcomings of 'conventional criminal' processes have led to a recent wave of interest and investment in 'innovative' and 'restorative' justice alternatives for sexual violence. It is critical that, as alternative justice processes or pathways are promoted and hopefully better coordinated, victim/survivors are given greater say about what they would like to happen, as well as information and advice about which justice pathways or options may best suit their needs. Indeed, affording the survivor some agency in decisions about processes and forms of redress will be critical to these being genuine 'alternatives' to the criminal justice response.

\section{Proposal 3: A national legal response}

Sexual violence is a pervasive and wicked social problem. It is not caused by, but it is not helped by, divergent legal provisions and inconsistent legal enforcement across the different Australian jurisdictions. There has been a strong degree of convergence in the criminal provisions governing sexual offences in the various Australian jurisdictions over the past 10-20 years, so the call for consistency may seem less urgent now than it was when model criminal codes were being developed in the 1990s. But there are still problems at the borders (literally) in terms of different investigation and charging practices on either side of state lines, problems for the public in understanding the different terms used to label offences in different jurisdictions, and problems in the differential treatment of offenders and victims depending on the prosecuting jurisdiction. For victims and offenders, a postcode lottery should not determine the services, programs and choices available.

To address similar problems in relation to family violence, the Australian Law Reform Commission ${ }^{13}$ has called for development of 'a common interpretative framework', to be applied across relevant state, territory and Commonwealth legislation, that establishes a shared understanding of: the nature, features and dynamics of family violence; core purposes of legislative schemes; and guiding principles for equality of treatment of family violence victims, with coordinated responses administered (for all intents and purposes) through a 'single court'. Hopefully, the current pressure to integrate (or at least coordinate) family violence and sexual assault responses - which have historically been handled within civil and criminal frameworks respectively - will mean that sexual assault is also

13 ALRC, Family Violence: A National Legal Response (Report 114, 2010). 
understood to require a consistent national response. If the justice needs of victims/survivors are to be appropriately supported, strategies, services and responses to sexual violence must be consistent and coordinated, nationally.

\section{Conclusion}

To ensure that the law provides and supports effective redress for sexual violence victims/survivors, law reform should:

- institute judge-alone trials for common sexual offences;

- promote civil law and civil-society 'alternatives' to criminal prosecution;

- develop a national legal response that promotes consistency in approach, and equality in treatment and service access, across the jurisdictions.

I hope it will not take another 25 years to see these proposals realised. 
This text is taken from New Directions for Law in Australia: Essays in Contemporary Law Reform, edited by Ron Levy, Molly O’Brien, Simon Rice, Pauline Ridge and Margaret Thornton, published 2017 by ANU Press, The Australian National University, Canberra, Australia. dx.doi.org/10.22459/NDLA.09.2017.11 